\title{
Beck Lethality Scale
}

National Cancer Institute

\section{Source}

National Cancer Institute. Beck Lethality Scale. NCI Thesaurus. Code C118792.

A scale for scoring the potential degree of medical lethality of various means of suicide, consisting of zero, low, medium, or high. 